\title{
The Ecological Catastrophe: The Political-Economic Caste as the Origin and Cause of Environmental Destruction and the Pre-Announced Democratic Disaster
}

\author{
Donato Bergandi \\ Muséum national d'Histoire naturelle, Paris, France \\ WAR IS PEACE \\ FREEDOM IS SLAVERY \\ IGNORANCE IS STRENGTH \\ - George Orwell - Nineteen Eighty-Four \\ ENVIRONMENTALISM IS DEVELOPMENT ${ }^{1}$ \\ - The Quintessence of the Sustainable Development Worldview
}

\section{The Roots of the Ecological Disaster}

We are living in a very advanced stage of a dystopian ecological catastrophe. At the planetary level, relatively few humans are consistently conscious of the deterioration of the life-support systems that allow life to persist and evolve on this planet.

In the meantime, the destruction of nature means enrichment for a tiny part of humanity, and goes hand in hand with severe environmental and economic losses for the great majority. This is particularly true in developing countries, where there still is an environment able to sustain higher levels of biodiversity in comparison to the environmentally more fragmented, economically advanced countries.

In any case, as a general trend, the populations of the developing and advanced countries must endure the exploitation of the planet's ecosystems and resources by an influential minority. In many cases, the populations have to face environmental disruption brought about by economic activities that are a source of enrichment for the few but the cause of pollution and environmental destruction for the many. Yet these same populations also contribute to the degradation of the environment because of their non-sustainable activities aimed at their survival and development.

It is becoming more and more evident, and even fastidiously trivial, that an influential minority, an oligarchic political-economic elite, a caste, ${ }^{2}$ is in charge of all the economic flows and uses of biodiversity at the global and national level. Their management of resources is substantially autocratic and homogeneous, and above all it is, to a very great extent, independent of their declared political reference system of values. In other words, the political components of the caste may well belong to opposite poles of the political spectrum.

\footnotetext{
${ }^{1}$ Another slightly more explicit way to express the attitude of the sustainable developmentparadigm towards nature is the following: PROTECTION OF NATURE IS DEVELOPMENT.

${ }^{2}$ This is a group of individuals made by tacit alliance between professional political elites and economic elites (industrialists, financial groups) who are fully aware of their interests, rights and privileges. Their social status is definable in terms of a new hybrid sociological space merging the categories of "corporation" and "caste". The latter is hereditary, while the hereditary dimension in the corporation is not necessarily present. The national and international political-economic oligarchy, with its sectarianism towards anyone not belonging to the group, has now acquired the pre-eminent features of a caste. The ideology and caste feeling imply a consciousness of belonging to a group with privileges and duties in a hierarchical context characterized by hereditary specialization and repulsion with regard to those who do not share this same social status (Bouglé [1935] 1969, pp. 3, 29).

D. Bergandi (*)

e-mail: bergandi@mnhn.fr

(c) Springer International Publishing AG 2017 L. Westra et al. (eds.), The Role of Integrity in the Governance of the Commons, DOI 10.1007/978-3-319-54392-5_12
} 
Nevertheless, the economic strategies towards biodiversity are fundamentally the same and are generally free from any concern about the balance and integrity of ecological systems and the environmental and economic well-being of the general human population.

The cutting edge of this global environmental destruction is the ethical-political model of sustainable development; its undeclared purpose is to show that a new phase of human economic and cultural development has started, that "everything has changed", without genuinely calling into question the economic production system, which is the first and main cause of the ecological disaster we are living.

The sustainable development paradigm did not start with the Brundtland report (Our Common Future, 1987), but results instead from a long history that finds its roots in the nineteenth century and that gradually emerged from a succession of events that studded the twentieth century (Bergandi and Blandin 2012). ${ }^{3}$ Gifford Pinchot (1865-1946), an American forester and politician, started the movement for the conservation of that nation's resources. His conception of conservation was essentially based on economic considerations. Conservation, for Pinchot, clearly and emphatically stands for "development". It is the affirmation of the right of any generation, present or future, to use the Earth's resources for their benefit. The actual model of sustainable development, with its recurrent reference to the conservation of resources and to future generations, has been clearly not only anticipated, but built, by Pinchot, at least in its normative basis: "Conservation does mean provision for the future, but it means also and first of all recognition of the right ofthe present generation to the fullest necessary use of all the resources that this country is so abundantly blessed with. It means the welfare of this generation and afterwards the welfare of the generations to follow" (Pinchot 1910, p. 42).

Conservation was also the prevention of waste: "So we are coming [. . . ] to understand that the prevention of waste in all other directions is a simple matter of good business. The human race controls the earth it lives upon" (Ibidem, p. 45). Finally, the "public good" was the metaprinciple to which all others were subordinated. Pinchot expresses his utilitarian credo along the lines of Jeremy Bentham (1748-1832) and John Stuart Mill (1806-1873): "Conservation means the greatest good to the greatest number for the longest time" (Ibidem, p. 48). It is interesting to note that, in the name of equality of opportunity for citizens, Pinchot also proffered a programmatic fight against the monopolies on the grounds that their influence could orient legislation in favor of their interests and against the public good (Ibidem, pp. 24 $30)$.

But Pinchot's formal battle against the monopolies failed to stand the test of politics. In fact, following the devastating 1906 earthquake in San Francisco, the city needed water and electricity. Even though different possibilities existed for supplying these, Pinchot supported the economic groups who sought to build a dam in the Hetch Hetchy Valley in California's Yosemite National Park. John Muir (1838-1914), and all those who would protect the integrity of Yosemite Park, fought a media and political battle, but in the end "ravaging commercialism" (Muir 1912, p. 262) won the day, and the dam was built. Pinchot's conservationism-oriented management of nature and his priority on human use- "wise use", of course - of the planet's natural resources started down the road of the harmful, damaging ideological utopia that today we call "sustainable development".

\footnotetext{
${ }^{3}$ Other key moments in the history of the sustainability paradigm are the Biosphere Conference (1968), the Stockholm Conference (1972), the Rio de Janeiro Earth Summit (1992), the Johannesburg Summit (2002), and the Rio + 20 Earth Summit (2012).

D. Bergandi (*)

e-mail: bergandi@mnhn.fr

(C) Springer International Publishing AG 2017 L. Westra et al. (eds.), The Role of Integrity in the Governance of the Commons, DOI 10.1007/978-3-319-54392-5_12
} 


\section{Caste, Democracy and Nature}

Before analyzing the significance and the practical impact of the sustainable development paradigm, in a propaedeutical way we must ask whether some ways of organizing power are more sensitive or intrinsically dangerous than others with respect to the protection of nature. Assuming that a totalitarian regime would represent the worst-case scenario, because a very limited number of people could decide on the environmental well-being of all the people, we limit the analysis to representative and direct democracy.

The harmful effects of the economic and financial activities of the lobbies and monopolies on nature are the ultimate consequence of a political danger that is always present in all forms of government. This danger has been very well identified by some of the founders of political liberalism. Bentham, treating the moral and political actions of individuals and communities, introduced a specific interpretative category to stigmatize the lethal danger of a full democracy, that of "sinister interests". These rogue interests privilege individual or group interests instead of encouraging the greatest happiness for the social community as a whole.

They tend to steer action in the wrong direction, in the sense that they determine unethical acts, acts of improbity that affect other people and are contrary to the interests of the community (Bentham 1815, $\S \mathrm{V}$, pp. 110-111). For his part, Mill, like Bentham, is extremely clear about the fact that no form of government is immune from the antisocial behaviour of elites in charge of the political management of the nation, and that such behaviour could harm and go against the development of the community: "One of the greatest dangers, therefore, of democracy, as of all other forms of government, lies in the sinister interest of the holders of power: it is the danger of class legislation, of government intended for (whether really effecting it or not) the immediate benefit of the dominant class, to the lasting detriment of the whole. [. . .] If we consider as a class, politically speaking, any number of persons who have the same sinister interest [...] the desirable object would be that no class, and no combination of classes likely to combine, shall be able to exercise a preponderant influence in the government" (Mill 1865, pp. 127-128). Along the same line of thought, in On Liberty, where he traces the history of the emergence of representative democracy in Europe, Mill develops the positive side of a legitimate ruling class: "What was now wanted was, that the rulers should be identified with the people; that their interest and will should be the interest and will of the nation" (Mill [1859] 1864, p. 10).

The lucid analysis by Bentham and Mill about the dangers that threaten representative democracy finds insightful echoes in the political philosophy and sociological analysis of Vilfredo Pareto (1848-1923), Gaetano Mosca (1858-1941), and Charles Wright Mills (19161962). First, it is philosophically and politically sounder not to use an interpretive filter of conspiracy theory, because the various actors belonging to a ruling class will, simply keeping their minds on their business and "following the lines of least resistance", find a convergent interest that shapes their political action: "That accord comes about automatically; for if in a given set of circumstances there is one line of procedure where the advantage is greatest and the resistance least, the majority of those who are looking for it will find it, and though each of them will be following it on his own account, it will seem, without being so, that they are all acting in common accord" (Pareto [1916] 1935, §2254, p. 1576).

Second, Mosca, for his part, considers that in political affairs the dominion of organized

\footnotetext{
D. Bergandi (*)
}

e-mail: bergandi@mnhn.fr

(c) Springer International Publishing AG 2017 L. Westra et al. (eds.), The Role of Integrity in the Governance of the Commons, DOI 10.1007/978-3-319-54392-5_12 
minorities over the unorganized majority is an inevitable outcome (Mosca 1896, chap. II, $\S 4$, p. 53). However, even if in our democratic societies the political struggle between individuals and groups is no longer a struggle for existence but a "struggle for pre-eminence" (Mosca 1896, chap. I, §13, p. 29; chap. V, §2, p. 121), we must keep in mind that when the governing class is the exclusive interpreter of the "will of the people" and no other organized social force can resist their "natural tendency" to abuse their powers, this means that "a despotism based ostensibly on popular sovereignty" has taken place (Mosca 1896, §6, p. 134).

Third, Mills, with his theory of the elite, sheds light on the sociological significance of institutional and social hierarchies in the United States and, more generally, in modern societies. His aim is "[. . .] to understand the facts of power and the ways of the powerful". The history of our political institutions results neither from a "blind drift" nor from a "conspiracy" of an unknown group of individuals (Mills [1956] 2000, p. 27). Alongside ordinary men and women who pursue projects that are beyond their control, the large majority, there is another category of men and women who rule the big corporations, who run the machinery of state, and who direct the military establishment. This "power elite" can make decisions that have major consequences, because they occupy the strategic command posts of the social structure (Ibidem, p. 4). The economic, the political and the military domains shape modern life via an "interlocking directorate" of people who are not always aware of their effective power (Ibidem, p. 8). However, at the top of the three enlarged and centralized domains, the economic, political and military elites form a compact social and psychological entity; they have become self-conscious members of a social class that tend to think and behave in very similar ways (Ibidem, p. 11). All this concentration of power in the hands of a few makes a mockery of democracy (Wolfe 2000, "Afterword", 364; similarly, John Stuart Mill considered that "exclusive government by a class" usurped the name of democracy, 1865, p. 163).

Political confrontation over the possession of a territory and its resources or for the preeminence of a specific political model once took the form of a gladiatorial fight, not unlike "nature red in tooth and claw". Today, although this is still a possibility, and unfortunately all too often an actuality, confrontation tends to be ritualized, and parliamentary debate takes the place of fighting. In a representative or indirect democracy, the exercise of legislative power is delegated to representatives of citizens who govern in the supposed interest of the people. If formally sovereignty lies in the people (i.e., in each citizen voter), in practice the exercise of the vote, the expression of freedom and autonomy, implies the delegation of decision-making power to representatives who should govern while pursuing the "common good". Paradoxically, then, in a system of representative democracy, the power of citizens is limited to delegating their "sovereignty" to representatives. But as Jean-Jacques Rousseau clearly noticed: "Sovereignty cannot be represented for the same reason that it cannot be alienated; it consists essentially in the general will, and the will cannot be represented; it is itself or it is something else; there is no middle ground. [. . . The English nation thinks that it is free, but is greatly mistaken, for it is so only during the election of members of Parliament; as soon as they are elected, it is enslaved and counts for nothing" (Rousseau [1762] 2002, p. 221). De facto, the citizens, still formally sovereign at the moment of voting, lose their decisionmaking power to representatives, who are required to engage in governance that will set aside individual or group interests, and will focus, at least in theory, on the interests of the whole community.

In contrast, in the case of direct democracy, "government of all the people" means that all the people govern directly on their own: they participate directly in affairs of state without

D. Bergandi $(*)$

e-mail: bergandi@mnhn.fr

(C) Springer International Publishing AG 2017 L. Westra et al. (eds.), The Role of Integrity in the Governance of the Commons, DOI 10.1007/978-3-319-54392-5_12 
any mediation or intermediary between them and the law, without any alienation of the decision-making power of the people. The citizens are involved directly in lawmaking via petitions or referenda that they themselves initiate: they draft laws, place them directly on the ballot, and then reject or approve them (Haskell 2001, p. 49). A government by assembly exercises its functions without delegates, and any delegates that do exist have received specific, revocable, binding mandates from the electorate (Bobbio 1989, pp. 154, 155).

In the paradigmatic example of Athenian direct democracy, the officials were chosen by lot, they could serve "only for one year and no more than twice in a lifetime" (Osborne 2010, p. 28 ), and even if, as was very likely, not all citizens could participate in the Assembly, decisions were reached after debate (Thomas 2000, pp. 61-62). There were no professional politicians, because quick turnover maintained the system in a permanent state of healthy and reinvigorating, incorruptible "amateurism".

Even according to the normative terms of representative democracy, Western democracies resemble pseudo-democracies more than they do fully functioning democracies. A new political ethos able to involve the population in governing a democracy more directly should orient the political system towards incorporating specific directly democratic procedures. Certainly, one norm with decisive importance for a successful democratic adventure is the choice of "temporary" officials who would be "chosen by lot" a limited number of times in their lifetime (no more than once or twice). This rule prevents democracy from becoming a partitocracy, i.e., a system of governance by parties that ultimately leads to a focus on clan relationships and on the establishment of a parallel and masked underground power. The emergence of such an elite of political professionals is the very negation of democracy. The noteworthy reduction of the number of representatives in parliament should go hand in hand with a predominant recourse to direct initiatives, popular referenda and recalls (citizens can remove and replace public officials before the end of their term of office). Finally, officials would no longer receive their mandate from a political party, but directly from the electorate: a mandate that is binding and that can be revoked if not respected.

The current system of representative democracy is completely disconnected from what should be its main purpose, i.e., the pursuit of the "common good". The antidemocratic involution of the system is such that, for example, both the United States and Europe (the European Commission) have begun a "lobbying register" of the corporates that want to influence law-making! In this kind of context, sovereignty has ceased to be "popular" and has become instead "corporate sovereignty". Of course, the economic power of these corporates enables them to exercise disproportionate pressure on the decision-makers, obtain privileged access to information and steer European and US laws and rules. History tells us that the influence of the corporates on lawmakers greatly outweighs that of citizen associations. This system clearly supports private, "sinister" corporate interests against the social interests and right of the people to enjoy a healthy environment. To list just a few environmental issues where this holds true: pesticide use, genetically modified organisms, rock hydraulic fracking and pollution by the chemical industry.

In the context of representative democracy, the sinister interests of the ruling class, of the oligarchic political-economic caste, constituted by professional politicians and corporate firms, represent a danger for the balance of human society and for its harmonious development with respect to social justice and equality of opportunity. In a very similar way, at the level of the biosphere the impact of the human species on the biodiversity and lifesupport system is so extensive and devastating that, at least at first glance, we can talk about human sinister interests capable of altering evolutionary processes and the ecological balance

D. Bergandi (*)

e-mail: bergandi@mnhn.fr

(c) Springer International Publishing AG 2017 L. Westra et al. (eds.), The Role of Integrity in the Governance of the Commons, DOI 10.1007/978-3-319-54392-5_12 
of biotic communities. But in reality the political and economic choices of an influential minority are connoting the sense of action of the entire human species. An influential minority that presume that they are still fully within their rights even as they stubbornly continue to manipulate the political rules and violate natural laws.

\section{Protection of Nature Is Development}

The battle to build an international organization for the protection of nature startedin 1913 and lasted 35 years. ${ }^{4}$ After two world wars, the International Union for the Protection of Nature (IUPN) was finally founded at Fontainebleau, France, in 1948. But whatever hopes this organization might have represented for its preservationist supporters were short-lived. Unfortunately for the fate of the integrity of nature, at the IUPN general assembly in 1956, under pressure from the Anglo-Americans, the organization changed its name to the International Union for the Conservation of Nature and Natural Resources (IUCN). For those gathered, the "Protection of Nature" was sentimental and unrealistic (Holgate 1999, pp. 63$65)$.

In reality, this change of name is not so harmless as it might seem at first glance. It is emblematic of a deeper influential trend: Pinchot's "wise" conservationism won the political battle for the "management" of nature. With conservationism, which does not question at all the destructive reach of the dominant economic model, the roots of ecological catastrophe were planted. All this was happening in a very noxious way, because conservationism, and today its direct filiation, sustainable development, represent a political alibi that screens the true essence of things: they support in the present everyday reality the destruction of the very ecological systems that they are supposed to defend, in the name of a never realized, or still in progress, "wise use" or "sustainability".

Day after day, the dystopian ecological catastrophe is taking an increasingly Orwellian form. The mainstream way of thinking conveyed by the sustainable development paradigm proposes ways of living and policy making that are supposed to definitively solve the planetary problems of the erosion of biodiversity and climate change. What is the solution to all our environmental problems? In a very concise way the philosophy of sustainable development can be efficaciously summarized as follows: "Protection of nature is development". "Sustainable" development, of course. . .. This is a paradoxical and oxymoronic sentence, but, at first glance, why not? This is the inner, deep message of the sustainable development "Newspeak" paradigm, carrying what George Orwell named "Doublethink" (Orwell's italicization), that is, "the power of holding two contradictory beliefs in one's mind simultaneously, and accepting both of them" (Nineteen Eighty-Four, [1949] 1959 , p. 220). In fact, sustainable development policy implies simultaneously antithetic and irreconcilable theoretical positions: (1) the preservation of nature and the conservation of nature, that is, the sustainable developmental "wise use" of nature; (2) the recognition of the intrinsic value of nature, which involves the substantial intangibility and respect for the integrity of ecological systems and for the extrinsic value of nature (i.e., the use of nature as a function of human instrumental needs and aims) (see Preamble CBD, 1992); and (3) the maintenance of ecological sustainability, i.e., the capacity of ecosystems to retain their

\footnotetext{
${ }^{4}$ The Berne Conference for the International Protection of Nature in 1913 was the first international meeting on this issue.

D. Bergandi $(*)$

e-mail: bergandi@mnhn.fr

(C) Springer International Publishing AG 2017 L. Westra et al. (eds.), The Role of Integrity in the Governance of the Commons, DOI 10.1007/978-3-319-54392-5_12
} 
essential functions and processes and to maintain their biodiversity and evolutionary potential over the long term (resilience), and upholding economical sustainability, so-called sustainable developmental growth in a context of human demographic increase and a world of finite natural resources (Bergandi 2013).

The sustainable development paradigm is structured around this "doublethink" and what we can identify as its practical corollary, the "double-act".

From the theoretical point of view and the "doublethink" side, there is in fact a deep ethical tension and antinomy between the preservation of nature, the preservation of its evolutionary potential, the safeguard of the balance of ecological systems and support for all this at the same time that one is holding the idea that "nature" is in essentia "natural resources". In other words, the complete philosophical and political failure of the sustainable development paradigm results from the deep "doublethink" inconsistencies that put an anthropocentric perspective side by side with the idea that ecological systems are bearers of values that transcend economic utilitarianism. Independently of any reference to categories such as "sustainability" or "intrinsic value", the underlying philosophical cornerstone of sustainable development is "anthropocentric", because the only happiness or wellbeing considered is, at best, that of all individuals of the human species, and "resourcist" because it considers that nature is nothing but a pool of resources and means that are functional to human well-being.

From the practical point of view and the "double-act" side, things become, if possible, even more complicated, because in the sustainable development Newspeak paradigm appears a word that in recent decades had almost vanished because it conveyed antinomian meanings with respect to ecological sustainability: the dreaded word is "growth"-but, of course, "growth that benefits all" (UNCSD Rio + 20 2012, p. 2). Other magic words that make their first appearance in this type of text include the "green economy", which "in the context of sustainable development [. . .] should contribute to meeting key goals [such as] sustained, inclusive and equitable growth [...] (Ibidem, p. 25)."

Later, at the Conference of the Parties (COP 21) in Paris in 2015, after almost 50 years of international political exchanges on the approach to be adopted at the planetary level by environmental policy, the majority of the international community reached a consensus about the fact that "climate change represents an urgent and potentially irreversible threat to human societies and the planet and thus requires the widest possible cooperation by all countries" (FCCC/CP/2015/L.9). The international community agreed on the necessity "to strengthen the global response to the threat of climate change, in the context of sustainable development and efforts to eradicate poverty... to pursue efforts to limit the temperature increase to $1.5{ }^{\circ} \mathrm{C}$ above preindustrial levels" (Art. 2, FCCC/CP/2015/L.9).

There is clearly a discrepancy between the facts and the civilized, magnificent, almost transcendent world of international treaties. Following to the letter the paradigm of sustainable development in everyday life, we can readily ascertain that the satisfaction of the basic needs of the entire human population is still hypothetical, equality of access to natural and financial resources is not guaranteed, and the economy is doped because of distortions due to advantages gained by transnational economic groups at the planetary level. Above all, we can see clearly that the productivist, consumerist model of development, the very cause of the ecological disaster that we are living, continues to phagocytize the planet.

The recent past is not a harbinger of a reasonably optimistic future. In 2002, COP8 (New Delhi) made a commitment to achieve a significant reduction in the current rate of biodiversity loss at the local and global level by 2010. But in 2010, the 3rd Global Biodiversity Report found, for example, that the total abundance of vertebrates living in the

D. Bergandi $(*)$

e-mail: bergandi@mnhn.fr

(C) Springer International Publishing AG 2017 L. Westra et al. (eds.), The Role of Integrity in the Governance of the Commons, DOI 10.1007/978-3-319-54392-5_12 
tropics declined by 59\% between 1970 and 2006. Some current clues tell us clearly that the ecological catastrophe is not only established and unequivocal, but that it is even gathering pace. Since the early 1990s, anthropogenic pressure has led to the loss of $10 \%$ of our planetary wilderness. Even though the area benefiting from global protection has expanded in the last two decades (by 2.5 million sq. $\mathrm{km}$ ), an even greater area of wilderness has been lost (3.3 million sq. $\mathrm{km}$ ). Some 27 ecoregions have lost any remaining significant wilderness area, particularly in South America, which experienced a 29.6\% loss (Amazon basin), and Africa, with a 14\% loss (e.g., Northwestern Congolian Lowland Forests) (Watson et al. 2016, pp. 12). Considering that half of all clearing in tropical forests between 2000 and 2012 was illegal, conservation interventions in wilderness areas need to be funded proactively to sustain the ecological integrity of these areas (Ibidem, p. 5; Westra et al. 2008).

Given mankind's efficiency at destroying planetary biodiversity, through the exploitation of species and the increasing fragmentation of the environment and through the impact of industrial activities on the planet's environmental life support systems, it is becoming increasingly clear that abandoning the resourcist anthropocentric ethics underlying our nature management policies - i.e. sustainable development and the Pinchotian conservationism of resources - is a moral, economic and political obligation.

It is a political obligation, because the resilience of what we can now name socioecosystems is no longer ensured by a representative system of popular sovereignty that disconnects, more and more, the environmental well-being of the populations and the preservation of the balance of natural systems from the decisions taken by professional politicians, who are oriented instead toward the preservation of their privileges and the interests of an influential minority.

It is an economic obligation, because, in the long term, the current approach based on the exploitation of resources, using techniques that are not conceived in function of minimizing the impact on ecosystems, is harmful not only to the biosphere, but also to the socio-economic systems themselves, because the only target sought is the benefit that can be derived in the short to medium term.

And finally, it is a moral obligation, because our value systems guide our actions in the world. If we want to build a new and more harmonious relationship with our environment, it is necessary to choose an ethical option in which humanity is not separate from the rest of nature, as many of our myths and religions have taught us for centuries. An ethical option would sustain the idea that "humans are nature" and, on the basis that there is a substantial ontological and evolutionary continuity between humans and nature, would construct a coevolutive ecological ethics of "solidarity". In fact, humans are on this planet because of a concatenation of biotic and abiotic entities, processes and events. If our ethical options break this chain of solidarity to affirm a vaunted moral primacy of mankind, enshrining our erratic power over the rest of nature, our fate will, very likely, be sealed.

The current catastrophic conditions of the environment should be lived by humanity as a kind of moral challenge, a moral test emerging from our very recent and unruly technological and economic development. Our ability to meet this test will determine whether we are still able to live and evolve in our ecological niche, the planet Earth. We can solve the test positively only if our moral principles are in correspondence with the natural rules that govern the planet's ecological processes, our life and the life of our animal and plant companions on the evolutionary journey. 


\section{References}

Bergandi D (2013) «Epilogue: the epistemic and practical circle in an evolutionary, ecologically sustainable society. » In: Bergandi D (ed) The structural links between ecology, evolution and ethics. The virtuous epistemic circle. Springer, Dordrecht, pp 151-158

Bergandi D, Blandin P (2012) «De la protection de la nature au développement durable: genèse d'un oxymore éthique et politique » (Eng. transl.: « From the protection of nature to sustainable development: the genesis of an ethical and political oxymoron »). Revue d'histoire des sciences 65(1):103-142. doi:10.3917/rhs.651.0103

Bobbio N (1989) Democracy and Dictatorship. The Nature and Limits of State Power. University of Minnesota Press, Minneapolis

Bouglé C (1969) Essais sur le régime des castes. Presses Universitaires de France, Paris

Bentham J ([1815] 1983) A table of the springs of action. In: Goldworth A (ed) Deontology; together with a table of the springs of action; and the article on utilitarianism. Clarendon Press/Oxford University Press, New York/Oxford

Haskell J (2001) Direct democracy or representative government? Westview Press, Boulder Holgate M (1999) The green web: a union for world conservation. Earthscan Publications, London

Mill JS (1864) On liberty, 3rd edn. Longman, Green, Longman, Roberts \& Green, London

Mill JS (1865) Considerations on representative government, 3rd edn. Longman, Green, Longman, Roberts \& Green, London

Mills CW (2000) The power elite. Oxford University Press, Oxford/New York

Mosca G (1896) The ruling class. McGraw-Hill Book Company, New York/London

Muir J (1912) The Yosemite. The Century Co, New York

Orwell G (1959) Nineteen eighty-four. Secker and Warburg, London

Osborne R (2010) Athens and Athenian democracy. Cambridge University Press, Cambridge

Pareto V (1935) The mind and society, vol 4, 1st edn. Harcourt, Brace and Company, New York

Pinchot G (1910) The fight for conservation. Doubleday, Page \& Company, New York

Rousseau J-J ([1762] 2002) The social contract and the first and second discourses. Edited and with an Introduction by Susan Dunn; with essays by May, G., R.N. Bellah, D. Bromwich and C.C. O’Brien. Yale University Press, New Haven/London

Thomas R (2000) « The classical city. » In: Osborne R (ed) Classical Greece 500-323 BC. Oxford University Press, Oxford, pp 52-80

UN Conference on Environment and Development (1992) Convention on biological diversity, Rio de Janeiro, Brazil. Adopted 5 June 1992

UN Conference on Sustainable Development (Rio+20) (2012) The future we want. Resolution 66/288 adopted by the General Assembly on 27 July

UN Framework Convention on Climate Change (2015) 21st session of the conference of the parties to the UNFCCC (COP 21). Adoption of the Paris Agreement on 12 December 2015

Watson JE et al (2016) « Catastrophic declines in wilderness areas undermine global environment targets ». Curr Biol 26:1-6

Westra L, Bosselmann K, Westra R (2008) Reconciling human existence with ecological integrity. Earthscan, London

Wolfe A ([1956] 2000) «Afterword. »In: Mills CW (ed) The power elite. Oxford University Press, Oxford/New York, pp 363-381

World Commission on Environment and Development (1987) Our common future. Oxford University Press, Oxford/New York

\footnotetext{
Abstract

The political, economic and environmental policies of a hegemonic, oligarchic, political-economic international caste are the origin and cause of the ecological and political dystopia that we are living in. An utilitarian, resourcist, anthropocentric perspective guides classical economics and sustainable development models, allowing the enrichment of a tiny part of the world's population, while not impeding but, on the contrary, directly inducing economic losses and environmental destruction for the many. To preserve the integrity of natural systems we must abandon the resourcist anthropocentric ethical fiction that is the current moral foundation underlying our relationship with nature and instead promote the realization of a new developmental landmark for democratic institutions: direct democracy, i.e. democracy truly governed by the people for the people, and ultimately for nature as well.

D. Bergandi (*)

e-mail: bergandi@mnhn.fr

(c) Springer International Publishing AG 2017 L. Westra et al. (eds.), The Role of Integrity in the Governance of the Commons, DOI 10.1007/978-3-319-54392-5_12
} 